\title{
The Role of References in Custody Mediation
}

Le rôle des références dans la médiation pour la garde d'enfants

Alena L. Vasilyeva

\section{OpenEdition}

\section{Journals}

Electronic version

URL: http://journals.openedition.org/tipa/1945

DOI: 10.4000/tipa. 1945

ISSN: 2264-7082

Publisher

Laboratoire Parole et Langage

\section{Electronic reference}

Alena L. Vasilyeva, "The Role of References in Custody Mediation », TIPA. Travaux interdisciplinaires sur la parole et le langage [Online], 33 | 2017, Online since 14 September 2017, connection on 26

September 2020. URL : http://journals.openedition.org/tipa/1945; DOI : https://doi.org/10.4000/tipa 1945

This text was automatically generated on 26 September 2020

\section{(c) $(1) \Theta \Theta$}

La revue TIPA. Travaux interdisciplinaires sur la parole et le langage est mise à disposition selon les termes de la licence Creative Commons Attribution - Pas d'Utilisation Commerciale - Pas de Modification 4.0 International. 


\title{
The Role of References in Custody Mediation
}

\author{
Le rôle des références dans la médiation pour la garde d'enfants
}

\author{
Alena L. Vasilyeva
}

\section{AUTHOR'S NOTE}

The earlier version of the manuscript was presented at the annual conference of the International Communication Association held in Singapore, June 2010, and was part of the dissertation project "Creating Deliberation in the Context of Social Conflict: The Examination of Mediator Practices for Shaping an Interactivity in Dispute Mediation".

\section{Introduction}

1 Conflict can arise in any type of interaction. However, some types of discourse are specifically created to deal with conflict situations, and one of them is mediation discourse. Mediation talk is an institutional form of talk where the goal of interaction is to help disputants manage their conflict through deliberation. The participants of mediation sessions are expected to orient to the goal of mediation talk and follow its norms in their endeavor to settle the matter. A mediator does not make decisions for disputants but facilitates their decision-making. The focus of the current project is custody mediation, where mediators help divorced or divorcing couples to create an agreement in regard to custody and visitation arrangements for their child or children. This article examines references (i.e., mentions of someone or something) that participants make in the course of mediation sessions with the purpose of understanding how these references serve as indicators of whether the mediation session is on-task or off-task and a type of interactional resources mediators use to manage conflict. 
2 In institutional talk, participants have different roles and have different kinds of knowledge (Drew \& Heritage, 1992), which is reflected at the lexical dimension of talk. In line with this, the use of references can be a sign of this interactional asymmetry in institutional contexts. Research also shows that lexical choice can be used as an argumentative strategy (Muraru, 2012). The question is how mediators and disputants used references during a mediation session, as reflected in the transcripts of mediation sessions. More specifically, the issue of interest is how references function as indicators of being on-task or off-task and how the uses of references contribute to constructing or maintaining an on-task mode of the mediation session and shaping a specific form of interactivity in the context of conflict.

The following sections briefly discuss the research on conflict talk and on references, explain the methodological aspect of the study, and provide an analysis of examples from mediation transcripts to illustrate how the mediators use references to interactional products, people outside of the immediate situation (children and agents of an organization, in particular), and external matters related to the agenda of the meeting to create an institutionally preferred form of the interactivity. Upon describing the uses of references, the analysis will conclude with a discussion of how these practices shape the deliberation process in the course of mediation talk and how they were used to create an institutionally preferred interactivity. The article discusses how these basic features of organizing the interaction are consequential for conflict in institutional context and shows how they limit what becomes arguable during sessions. Finally, it comments on how the study improves the understanding of communication design and discusses the mediator's actions as "a designer in the situation" and design as a joint endeavor.

\section{Conflict and discourse}

Discourse studies highlight the importance of communication in constructing and transforming conflict situations (Putnam, 2009). In this respect, researchers of conflict talk are interested in interactants' use of interactional resources and techniques to create conflict or manage disagreement in interpersonal and institutional contexts (Aakhus, 2003; Black \& Wiederhold, 2014; Bonito \& Sanders, 2002; Coulter, 1990; Gillispie \& Chrispeels, 2008; Goodwin \& Goodwin, 1990; Hutchby 1996; Schiffrin, 1990; Stokoe \& Sikveland, 2016; Vasilyeva, 2015b; 2016b). For example, interactants can use shifts in footing as a resource to address disagreement in an indirect way while avoiding conflict (Bonito \& Sanders, 2002) or stay neutral (McVittie et al., 2011). Other strategies to shape disagreement space include limiting topical potential by the use of questions or introducing issues to discuss (Bilmes, 2001; Greco Morasso, 2011; Maoz \& Ellis, 2001; Vasilyeva, 2012a), activities of giving an opinion and telling a story (Schiffrin, 1990), providing accounts for one's actions and expressing agreement with an opponent (Vasilyeva, 2016b), and use of formulations, editing, framing, and reframing (Black \& Wiederhold, 2014; Putnam, 2009; Sprain et al., 2014; van der Houwen, 2009).

5 Focusing on citizen participation in school district's board meetings, Tracy (2010) identifies a number of discursive strategies citizens use to express their disagreement and outrage and to criticize the public officials' proposals such as feeling-limned 
descriptions (i.e., descriptions that reveal speakers' negative feelings), avowal of negative feelings (e.g., "I'm hurt"), rhetorical questions that were used at the end of the speech to sum up a speaker's argument that involved negative assessment of the board's actions, reported speech as a way of expressing a negative opinion of another while minimizing the likelihood that a speaker will be seen as unfairly negative to others (p. 88), use of god and devil terms (i.e., the terms that are associated with what is right or wrong in a particular culture, for example, the words "children" and "democracy" are god terms and "political" is a devil one in the United States), and employing meeting rules against the board members to highlight their violation of the code of behavior. While speakers can frame their own actions as legitimate criticism, these actions can be assessed as personal attacks by those who are the target of this communicative action (Tracy, 2010). As Tracy puts it, [t]hey are likely to describe their own actions and others they agree with in language that implies the goodness of their motives, and to do the opposite with those with whom they disagree (p. 184).

6 Specificity of conflict talk in multi-party institutional interactions is another area of research on conflict. According to Gillispie and Chrispeels (2008), such discursive practices as the juxtaposing and problematizing one's behavior and an "us-them" distinction can hinder collaboration and lead to conflict in a mutli-person interaction while using the pronoun "we", clarifying the participants' roles, and adopting the shared terminology contribute to building collaboration. One specificity of multiperson conflict talk is the construction of collaborative arguments (Kangasharju, 1996; 2002; Maoz \& Ellis, 2001). Studying collective disagreements, Kangasharju (1996) identifies devices the participants of a meeting use to align with a person who is in disagreement with another interactant, such as collaborative completion of the prior turn, upgrading assertions of agreement, and nonverbal means (e.g., a headshake, a smile, and laughter) and to disaffiliate from them (e.g., nonverbal means such as a gaze). Another research on meetings indicates that there are differences in the use of linguistic devices on conflict talk depending on the interactants' interpersonal and organizational relations of power (O'Donnell, 1990). For example, conflict talk between interactants with asymmetrical power relationship was characterized by less reciprocity in terms of speech strategies, modality, and pronominalization. Also, when the social distance was greater, the interactants were spelling out their positions on issues more explicitly, and their position turns were longer and uninterrupted (O'Donnell, 1990). The study of verbal conflict in the course of an election debate (Vasilyeva, 2016b) illustrates how multi-party interaction provides opportunities for constructing and managing conflict between the debaters and the moderators. On the one hand, it allows the candidates to address multiple aspects of the same issue, for instance, to challenge the moderators' actions from the point of face concerns or procedural violations. On the other hand, it gives an advantage to the moderators to terminate argument by giving the floor to another candidate and collaborate on making a transition between activities.

One of institutional contexts that is of great interest to researchers of conflict talk is dispute mediation (see Vasilyeva (2015a) for a detailed description of research on mediation discourse). Dispute mediation differs in approaches mediators use to manage conflict (e.g., narrative mediation (Bush \& Folger, 2005) and transformative mediation (Winslade \& Monk, 2008)) and issues that are the focus of mediation (e.g., divorce mediation (e.g., Olekalns et al., 2010), workplace conflict (e.g., Hoskins \& Stoltz, 2003), civil court cases (e.g, Wall \& Chan-Serafin, 2014), conflict between neighbors (e.g., 
Stokoe \& Sikveland, 2016), to name a few). Research on mediation demonstrates that mediators use a variety of techniques ${ }^{1}$ to manage interaction in the course of the session and help disputants deal with their conflict. For example, they accomplish that by formulating parties' complaints (Stokoe \& Sikveland, 2016), using linguistic devices to temporize the dispute, redirect the discussion, and relativize facts (Aakhus, 2003), controlling where in the course of interaction disputants report their position (Garcia, 2000), using requesting directives (Donohue, 1991), employing metaphors (Greco Morasso, 2011), advancing institutionally appropriate participants' identities and dialogue activities and discouraging institutionally dispreferred ones (Vasilyeva, 2012b; 2015b), selecting vocabulary items that aim to create communion between disputants (Muraru, 2012), and constructing their interventions in a way that would keep disputants in the frame of the mediation activity without threatening their image (e.g., by providing an account for terminating an institutionally inappropriate activity or topic) (Vasilyeva, 2017).

8 All these studies illustrate a great variety of interactional resources and techniques interactants can employ to construct confrontation and to manage conflict. All the things participants bring into interaction and moves they make contribute to expanding or limiting disagreement space (Jackson, 1992). One of the linguistic devices to shape interactivity that this article focuses on is practices of referencing, which will be discussed next.

\section{Reference practices}

9 The research on references sheds light on different aspects of reference practices, such as: the organization of references to persons in everyday interaction (e.g., Kitzinger et al., 2012; Lerner et al., 2012; Sacks \& Schegloff, 1979; Schegloff, 1996, 2007), the use of location formulations (e.g., Schegloff, 1972), and the formulation of time and action (e.g., Jefferson, 1996). More recent work on references has advanced our knowledge of the uses of reference in performing actions (e.g., Kitzinger \& Mandelbaum, 2013; Kushida, 2015; Land \& Kitzinger, 2007; Lerner et al., 2012; Lerner \& Kitzinger, 2007; Oh, 2007).

10 According to Schegloff (2007), mentioning people performs a variety of actions such as referring, describing, identifying, and formulating, and can be done with help of personal pronouns, names, category terms, and recognitional descriptors. The choice of term depends on initial or non-initial occasions of mention, the target of reference (e.g., the speaker, the addressed recipient or other person), and the familiarity of the recipient with the target of reference (Schegloff, 2007). For location formulations, the selection of the term depends on such aspects as the location of the participants, the membership identification in the interaction, and the topic or activity being taken at the moment (Schegloff, 1972). Also, by deploying a specialist term or a vernacular term (e.g., "pediatrician" versus "baby doctor") an interactant displays whether they treat their recipient as knowledgeable in a certain area or not (Kitzinger \& Mandelbaum, 2013). Thus, research demonstrates that in the production of references interactants orient toward the principles of the recipient design. In other words, interactants' use of references depends on who is the recipient of their talk and what knowledge they have (Lerner \& Kitzinger, 2007; Sacks \& Schegloff, 1979; Schegloff, 1972). 
11 Further studies on references have demonstrated that referring in the talk-ininteraction does more than mere referring, and that the choice of reference terms also depends on action formation (Land \& Kitzinger, 2007; Lerner \& Kitzinger, 2007; Oh, 2007; Schegloff, 1996). One example of how the forms of references are used to accomplish different interactional projects is the use of overt references to speaker and recipient in Korean (Oh, 2007). The speaker uses overt reference for self-praising, blaming, disagreeing, assigning responsibility, projecting their talk, or selecting the next speaker. Another example is the use of third-person reference forms for selfreference to represent the views of someone else (e. g., an organization) (Land \& Kitzinger, 2007). Focusing on the connection between a type of reference form and epistemics, Kushida (2015) demonstrates that a name-quoting descriptor (e.g., a place named $\mathrm{X}$ ) instead of a bare proper name is used to perform additional functions to referring, for example, downplaying the recipient's knowledge of the referent or indicating lack of independent knowledge about the referent.

Referencing can also display an interactant's attitude toward others and be employed in the identity construction (Kitzinger \& Mandelbaum, 2013; Tracy, 2011; Vasilyeva, 2015a; Whitehead \& Lerner 2009). For example, according to Kitzinger and Mandelbaum (2013), vocabulary selection demonstrates interactants' orientation toward their own identity and the identities of others. The use of specialized vocabulary invokes territories of expertise and indicates that an interactant is viewed as an expert (e. g, a childbirth expert) and a member of some speech community. Conversely, an interactant's avoidance of a specialist term can imply that the recipient of talk is treated as a novice. Kitzinger and Mandelbaum state, that a specialist term is preferable than a recognitional descriptor, as in case of the latter the recipient is seen as less knowledgeable and less educated. Undersupposing the recipient's competence may have negative consequences, as the recipient may find this offensive and challenge the co-interactant's action. Another example of the use of references in identity construction is mediators' practices in custody mediation (Vasilyeva, 2015a). Invoking the membership category of parents and collaborators out of many other possible identities the disputants of custody mediation may have, mediators focus them on task at hand (i.e., working out an agreement in regard to visitation and custody arrangement for their children) and distance them from their conflict.

Thus, the research on references demonstrates their importance in talk-in-interaction. The use of specific vocabulary contributes to building the interactants' identities, creating the context of talk, and performing a range of actions. The present article logically follows prior research on references in that it focuses on the role of references in signaling or constructing states of an activity. The article examines the use of references as indicators that interactivity is on-task or off-task and a type of interactional resources mediators use to manage conflict.

\section{Data}

The research uses the method of discourse analysis and takes the communication design approach (Aakhus, 2007; Jackson \& Aakhus, 2014). The communication design approach views communication as an object of design and a process of design (Aakhus, 2007). Communication design takes place when interactants intervene into a 
communicative activity with help of techniques, devices, and procedures (p. 112) to change this activity to achieve certain ends.

An existing collection of 18 transcripts $^{2}$ from audio recordings of mediation sessions at a mediation center in the western United States serves as a source of interactional data. The transcripts used in the present study are from sessions held in a public divorce mediation program, that is, a program connected with a court where the judge approves the decision that has been made in the course of the session (Donohue, 1991). In case disputants fail to reach an agreement, the judge makes a final decision (Donohue, 1991). The participants in the mediation sessions are mediators and couples going through a divorce or divorced couples. The mediation sessions under study were held in the mediator's office or a conference room in the court building. The disputants were usually seated side by side at some distance from each other. The sessions were conducted by 8 different mediators. All cases except one lasted one session. The length of sessions varied but in the majority of cases it was about 2 hours.

The mediation sessions are set up for the divorced or divorcing couple to develop arrangements for child care such as child custody and visitation rules. The role of the mediator in these sessions is to help disputants create or modify a child custody arrangement that would be best for their child. The mediator leads the discussion in the way that helps each party voice their position and manages troubles in reaching an agreement.

17 In the course of the mediation session, participants use different types of references. The specific tokens of references were categorized through a grounded, inductive approach that involved the examination of 18 transcripts of mediation sessions. This article focuses on the types of references that can serve as an indicator of interactants' orientation toward the task at hand. The pragmatic interest here is how the references as actions display an orientation toward the event for others to take up and create an on-task mode of the mediation session and are used to manage conflict.

\section{Types of references}

The mediator's job is to ensure that disputants understand what they are expected to do and keep them focused on the product while disputants are to develop a plan. In other words, disputants' task is to craft a product (e.g., an agreement), while mediators' task is to craft a designing system that allows disputants to do this in view of their conflict. References that are employed to create an institutionally preferred form of the interactivity are references to interactional products, to people outside of the immediate situation (children and agents of an organization, in particular), and external matters related to the agenda of the meeting.

\subsection{References to interactional products}

19 Parties enter a mediation session with the ostensible aim of reaching some agreement on arrangements for their children. The interactional product that they create in the course of the meeting can be a plan, an agreement, a contract, an order, or some decision. Thus, the references to these interactional products indicate the interactants' 
orientation toward being on task for others to take up. For example, in excerpt 1 the mediator centers the talk around creating a plan, which is the primary goal of the meeting.

5M: =that would probably be very painful to you, but if we can lay (come) these emotions aside for a moment and see if- if we can come up with some plan. Let's see if we can do that.

There are differences in mediators' and disputants' usage of this type of references. Mediators are the ones who make most references of this kind (192 out of 236). Interactants use different linguistic tokens to refer to the interactional product. Mediators tend to use linguistic tokens that are institutionally preferred for the conciliation court, for example, "statement", "arrangement", "order", "plan", and "agreement", the latter two being the most frequent tokens used on a whole. Disputants also use the tokens "arrangement", "plan", and "agreement" but not as often as the mediator. Disputants refer to the interactional products either in a vague manner, for example, "something written", "something", "thing" or use the tokens that are not quite accurate for a mediation session, for example, "contract".

\subsection{References to people out of the immediate situation}

In the course of a mediation session, interactants make references to different groups of people that are not present at the meeting such as children, neighbors, family members, acquaintances, colleagues, babysitters, agents of an organization (e.g., lawyers, judges, psychiatrists, counselors, the police, doctors, teachers, mediators), witnesses, religious groups, researchers, clients, abstract people, and unknown people. Some of these subtypes can be to some degree an indicator of interactants' orientation toward the task (or brought in when interactnats are focusing on task), for example, references to children, agents of an organization (e. g., judges, counselors, lawyers), clients, and abstract people. All these references are related to the process of dispute resolution and the interactional product to a certain degree. For example, children are the target of the interactional product; judges, lawyers, and counselors are people who can help to deal with the problem if disputants are not able to come to agreement in the course of a session. Other clients and abstract people serve as an example of what can be done to solve the problem.

The goal of a mediation session is to make arrangements for children, so it is not surprising that this type of references is brought in most frequently (if to compare to references to other people outside of the immediate situation) by all the participants of the meeting. However, when mediators bring in these references into interaction, it is task-related. When the parties make them, this is not necessarily the case. Mediators employ this kind of references to make the disputants keep in mind for whom they are crafting the interactional product. Disputants, in their turn, may exploit references to children to pursue their own agenda, that is, to depict themselves in a favorable light and to undermine the image of the other party. 

head of school or the police), it is mediators who refer most frequently to agents of an organization who are directly related to the process of dispute resolution (i.e., the judge, the attorney, the psychiatrist, the mediator). These references are employed to keep disputants on task. On the one hand, judges, attorneys, and therapists are introduced to avoid dealing with the issues that are out of the scope of the session. On the other hand, references to these agents are used to encourage disputants to stay in the session. Giving disputants an idea about options to resolve their problem, mediators often frame turning to these agents as less desirable than working out issues in the course of a mediation session as the alternative ways are more expensive and disputants have less or no control over decision-making. mediators often make references of more abstract nature (e. hypothetical parents, children, people who seek to solve custody and visitation issues in general). They use these references to provide parties with examples of how other people in a similar situation deal with their problem or how certain arrangements work.

It is also important to take into consideration vocabulary items interactants use to make their references. For example, they can provide grounds for analyzing how the conflict and disagreement are constructed. The way (ex)-spouses talk about children can be evidence of their opposition. When they bring them into the discussion, they use the pronouns my, your rather than our referring to the mutual children as it can be seen in excerpt 2 (e.g., "I'm gonna get my son back", "she pushed my son", "she told the police that my son had cigarette burns all over his body").

$27 \quad(2)$

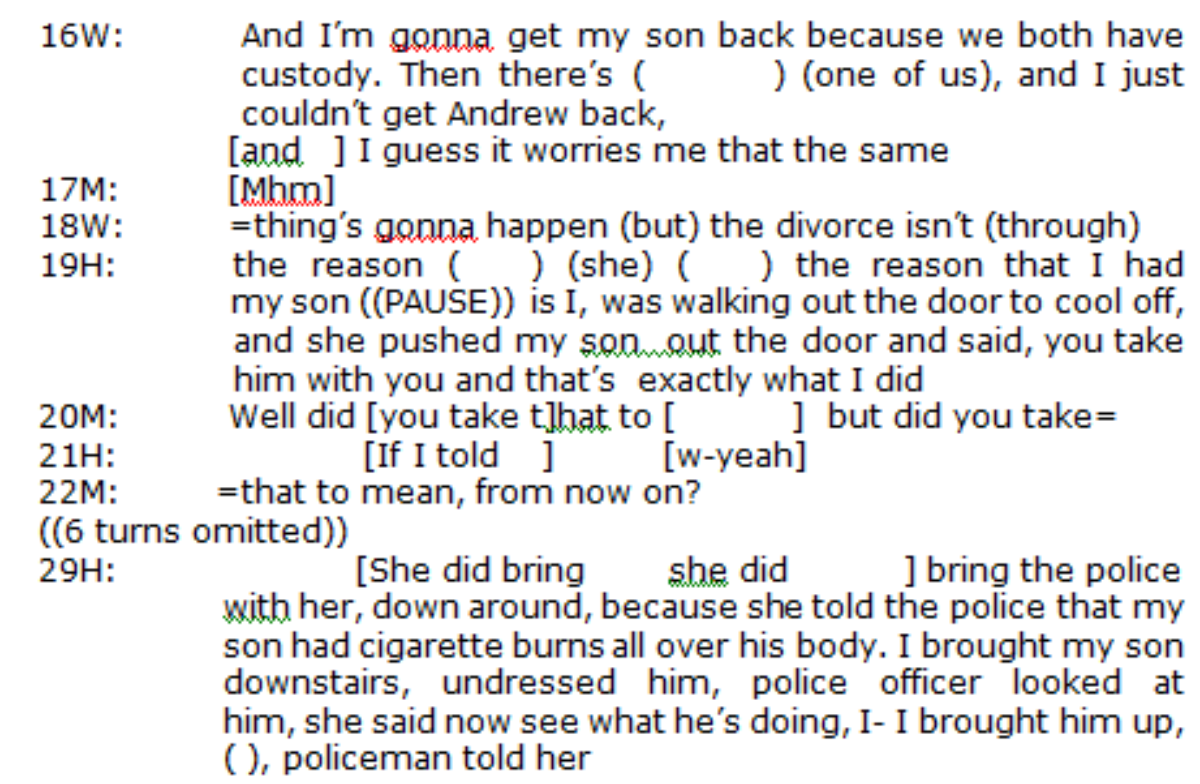

Here, the usage of personal pronouns indicates that $\mathrm{H}$ and $\mathrm{W}$ see themselves as separate units. As the pronoun my implies individual possessions, by employing it, the disputants exclude the other parent and show that they have more rights on the child than the other one. 


\subsection{References to external matters}

Among many things outside of a mediation situation that interactants refer to (e.g. location, occupation-related matters, events, and state of affairs), there are references that are directly associated with the task interactants are trying to accomplish in the course of a session, and, thus, they indicate their orientation toward the task. These are references to custody and visitation matters and the process disputants have to go through to resolve their dispute. These references are employed to shape a mediation activity and create a task-orientation mode. For instance, in excerpt 3 the (ex)-wife makes a reference to a possible future situation (namely, her job and schedule) that has to be taken into consideration in creating an agreement.

62W: Well I don't know exactly which days, I don't know if I'm gonna get the job I don't know what my schedule's gonna be and I go to school nine to twelve Monday through [Friday

All these references are important to note as they create the context for interaction and can be called on and become grounds for disagreement, conflict, strategic behavior, as well as for the rationales for a participant's position or ways to defuse a position of another party.

\subsection{Functions of references}

The references perform different functions. They are employed at the beginning of the discussion to set a task before the disputants and later in the course of the session to keep the discussion focused on task or to show that the conversation is off-task. This can be illustrated by the following example.

In excerpt 4 , the mediator sets up the scene for the session and explains to the disputants the reason for their coming to the conciliation court, the process of developing arrangements for children, the job mediators do, and what the disputants are supposed to accomplish in the course of the mediation session (i.e., to create a plan for their children). 
$3 \mathrm{M}: \quad$...Um, before, you go before the court to present your case or instead of hopefully, um, you come here to the conciliation court and our job is to assist you to see if you can talk through some of your issues, and work out a plan for your children, whereby they can be with you the father and you the mother. Um, because although you're getting a divorce from each other, you're not getting a divorce from your children, and your children need both of you, and the plan, the job before both of you is to work out some plan, where they can be with you as their mother and they can be with you as their father um, so it that could be worked out here, then (you could) write up an agreement, a plan, that you two have to come up with- with my assistance, and then that becomes an order of the court...

In this excerpt, $\mathrm{M}$ employs a number of verbal items (e.g., "an agreement", "a plan", and "it") to refer to the interactional product. There is a certain repetitiveness in the way these references are made. $M$ does not provide extra information but states again and again what can be accomplished during the session (e.g., "work out a plan for your children", "the plan, the job before both of you is to work out some plan", "it that could be worked out here, then (you could) write up an agreement, a plan, that you two have to come up with- with my assistance, and then that becomes an order of the court"). By doing that, $\mathrm{M}$ shows his/her orientation toward what this meeting is about and sets a task for the disputants to take on.

Two themes emerge from the context, in which these references are made. First, $M$ makes it clear that developing this interactional product is the primary goal for the disputants to achieve. Second, it should be done in a collaborative manner. The moves in excerpt 4 are persuasive moves about the nature of interaction, that is, they persuade about the kind of activity to participate in. Developing a plan presupposes actions that differ, for example, from reaching a verdict. When interactants are planning, they are oriented toward the future, they anticipate problems and consider ways to deal with them. They are not fixing grievances or distributing goods or resources to make up for what someone has lost. Thus, it presupposes that the parties act as collaborators. The use of references to interactional products in this context reoccurs across the sessions. Thus, when the conversation is centered on an agreement, a plan or alike, the interactants are acting in an on-task mode.

References made later in the discussion are used to keep the discussion going and disputants focused on the task. Mediators can bring the interactional product into the interaction to sum up what has been achieved in terms of agreement, to explain or clarify certain points, to ask parties to express their opinion on the interactional product, to suggest the wording of some statement or what kind of plan would be suitable for a particular case, to persuade the parties to have a written agreement, and to avoid impasse (e.g., by reminding the parties that they are developing a temporary plan, not a permanent one).

The following excerpt illustrates this function. The references the mediator and the exwife make to a visitation order show their mutual focus on task at hand. Prior to this episode, the discussion was on different visitation arrangements when the ex-husband suggested having a structured visitation order instead of the unstructured one they 
had at that moment. The conversation in excerpt 5 is centered on the interactional product that was the outcome of the preceding discussion.

$39 \quad(5)$
$116 \mathrm{M}$ : How do you feel about a structured visitation order like that Carry? $=$

$117 \mathrm{~W}$ : That's what I want to go by he's=

$118 \mathrm{M}: \quad=\mathrm{OK}=$

$119 \mathrm{~W}:=$ That's what I want to go by.

$120 \mathrm{M}$ : I think it'd be very easy for us to uh establish a court order (and) we would just plug \that into it. Say look at the- these are the visitation orders. This is what the visitation will be like. And yeah we can do it very easily here and you will sign it and so will Carry and ( $\quad$ ) there would be no need to come in on a- April seventeenth right?

In turn 116, M brings into the interaction the reference "a structured visitation order", which is taken by W in turns 117 and 119, where she uses the pronoun "that" to refer to the visitation order. In turn 120, M makes reference to this interactional product again ("visitation orders") and makes a reference to another interactional product ("court order", "it"). The connection of the references $\mathrm{M}$ and $\mathrm{W}$ bring into interaction indicates the interactants' mutual orientation to the matter of the discussion and being on task. $M$ makes reference to the interactional product after the disputants have discussed different options of visitation arrangements. The parties have agreed on certain aspects of visitation, and $\mathrm{M}$ gears them to complete the task in the course of the current session. The outcome of the session should be a particular kind of interactional product. At this point, the parties have already developed part of this product, that is, visitation orders, which means that they are on the right track. $\mathrm{M}$ makes a point that the final product, that is, the court order, can be easily established "here" at the meeting, which is a persuasive move to push the parties to complete the task. In a way, in this example, referring to the interactional product serves as a checkmark of the progress made in the course of the session so far, and it is a way to keep the conversation going and to keep the parties focused on task.

41 References can also function as an indicator that the disputants have gone off-task. In this function, they occur most often in the middle of the session. For example, they make references to agents of an organization to point out that they are the ones who should be dealing with certain issues (e.g., the financial aspect), not the mediator, as it can be illustrated by excerpt 6 . Prior to this episode, the discussion was on visitation time. The ex-wife would like to have a more structured form of visitation than they were having at the moment, as, in her opinion, it would be beneficial for the child and the parents. However, the ex-husband questions the ex-wife's intentions and supposes that there is a financial aspect involved in making this proposition. The mediator intervenes not to let the discussion go off-task.

$42 \quad(6)^{5}$

TIPA. Travaux interdisciplinaires sur la parole et le langage, 33 | 2017 
$184 \mathrm{H}$ : You need some structure by having me pay for you

(3 turns omitted)

$188 \mathrm{~W}$ : [Money] has nothing to do with this at this point=

$189 \mathrm{M}: \quad=$ It does and it doesn't all right?

$190 \mathrm{H}$ : It does [it does matter ]

$191 \mathrm{M}$ : [What's real important] what's real important Arnold is to come up with a plan that is good for Valerie. Apart from the money, Valerie simply needs to be with both of you.

192 W: Right

$193 \mathrm{M}$ : Okay after that's worked out then either the attorneys or the judge will work out the money.

In this excerpt, $\mathrm{H}$ brought into the interaction a financial aspect that is out of scope of the mediation session. $\mathrm{M}$ makes it clear that working out the financial matters are secondary at the moment, whereas working out arrangements for the child is the priority. $\mathrm{M}$ makes references to attorneys and the judge to shift the responsibility of dealing with this matter to people who are more appropriate to help the parties with this aspect of their disagreement as they have either more competence in that area or more authority. These references are a sign of M's orientation toward the task and are used to prevent the shift in the discussion.

The analysis shows that there are certain patterns in the reference usage that can be a sign of interactants' focus on task. However, these references should not be abstracted from their surroundings, as bringing in a certain type of reference is not a guarantee that the discussion is on task. The following section will focus on the importance of taking into consideration the local context of the reference usage.

\subsection{References in the context}

It was mentioned before, for instance, that references to children can be an indicator of an on-task mode as children are the reason for having this meeting and the ones who are affected by its outcome in the first place. This on-task orientation is usually true in regard to what the mediator brings into the discussion, while disputants' references to children are not necessarily task-related, which is illustrated by excerpt 7 . All the way through interaction here, the interactants make references to the child. However, the focus of the discussion is gradually shifting from visitation arrangements to the behavior of one of the disputants.

$46 \quad(7)$ 


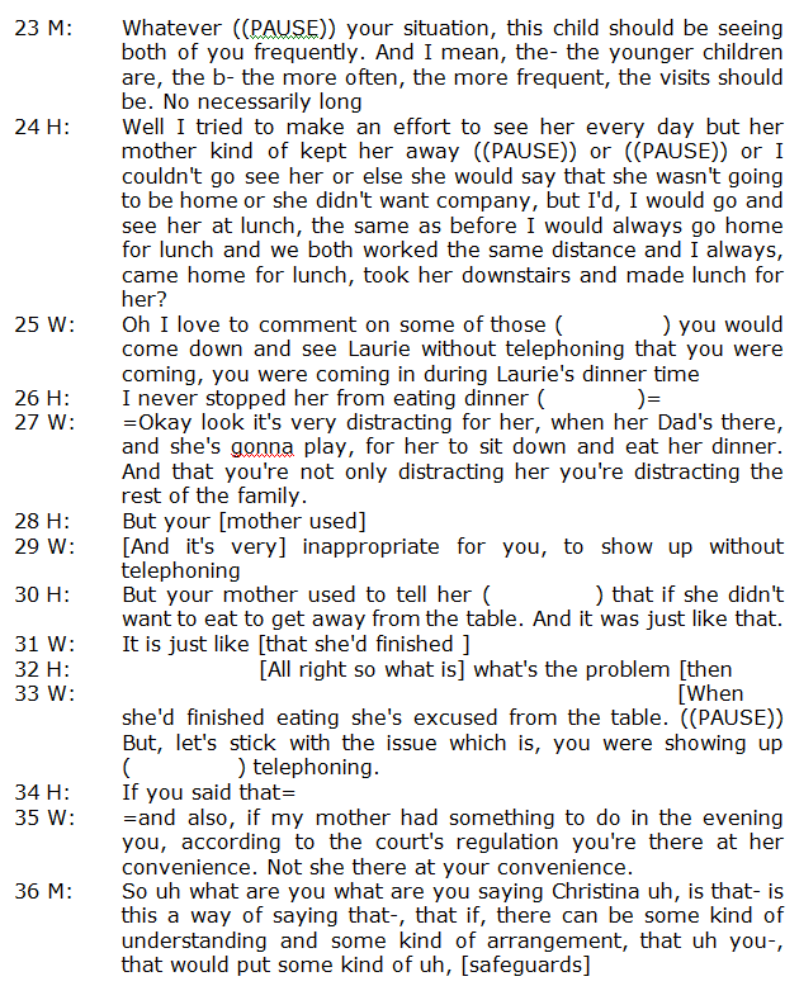

In turn 23, $\mathrm{M}$ stresses the importance of the presence of both parents in the child' life and the necessity for young children to see them frequently. $\mathrm{H}$ makes a point that he did his best to see his daughter every day but she was kept away from him (turn 24). Next, $\mathrm{W}$ accuses $\mathrm{H}$ of coming to visit their daughter Laurie without notice and at inappropriate time (turn 25). In turns 26-35, the interaction is basically centered on the issues whether H's visits distract Laurie from having dinner, except turns 29 and 33 where $\mathrm{W}$ brings back the issues of visitation without telephoning and turn 35 where she refers to the court's regulation in regard to visitation rules. W's point is taken on in turn 36, where $\mathrm{M}$ refers to visitation arrangements.

In the excerpt above, $\mathrm{M}$ makes references to children and visits, focusing on the frequency of visitation for young children, and thus, being on track. In the subsequent turns, $\mathrm{H}$ and $\mathrm{W}$ keep referring to their child, so on surface they may seem to be orienting toward the task as the child is still part of interaction. However, other references they bring into the discussion indicate a shift in it. If in turns 24 and 25, the focus is still partially on the visitation issues such as visitation frequency and time (e.g., the references "every day", "lunch", "dinner time"), in turns 26-34 the focus is on past events. W describes these events in terms of H's behavior and accuses him of distracting Laurie from having dinner while H's position is that the child's behavior at dinner was usual and in line with what W's mother told her to do. $\mathrm{H}$ and W mostly make references to W's family members (e.g., "your mother", "the rest of the family") and the process of having a meal (e. g., "dinner", "the table"). W's comment in turn 33 directly indicates that the discussion has gone off track. She points out that the child's behavior during dinner is not the issue in question but H's showing up without notice. This issue is related to visitation matters, which is evident in M's subsequent turn where $\mathrm{M}$ checks what $\mathrm{W}$ is saying and makes reference to visitation arrangements. The discussion continues in an on-task mode. 
he combination of different types of references, on the other hand, can indicate an on-task mode of interaction, which is exemplified by excerpt 8 . In this example, the focus of the discussion is on the arrangement for the children. The ex-wife wants to move out of state together with the children, and the ex-husband would like the kids to stay with him. The mediator makes a point that the ex-husband can try to bring this case to court, however, the chance for him to get custody over the children is not great. Instead, the mediator offers an opportunity to develop a visitation plan during the session. This discussion is task-related, and the orientation to the task is revealed through different types of references such as the interactional product, people outside of the immediate situation, and external matters.

(8)

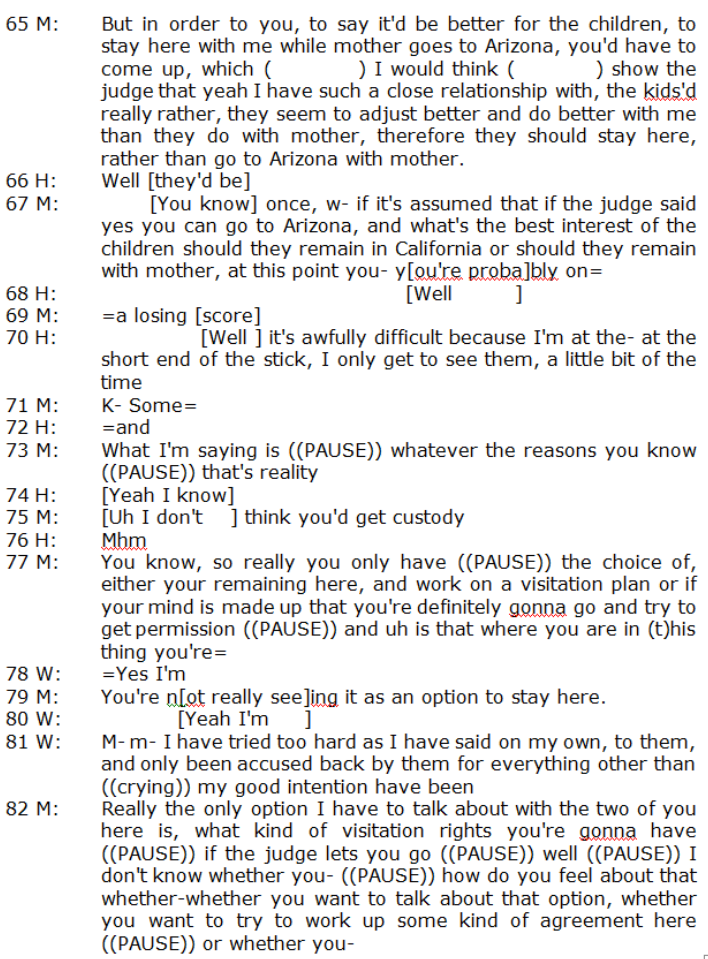

In this excerpt, $\mathrm{M}$ makes a number of institutionally relevant references that all together contribute to creating an on-task mode of the discussion. First of all, there are references to external matters that are directly related to the agenda of the meeting such as custody and visitation matters (e.g., "the time" in turn 70, "custody" in turn 75, "a visitation plan" in turn 77, "visitation rights" in turn 82). Next, there are references to people outside of the immediate situation who are the primary target of the meeting, that is, children (e.g., "the children" in turns 65 and 67, "they" in turns 65-67, "them" in turn 70, "the kids" in turn 65), and an agent of an organization involved in the process of dispute resolution (e. g., "the judge" in turns 65,67 , and 82). $\mathrm{M}$ also makes reference to the interactional product to be created in the course of interaction (e.g., "agreement" in turn 82).

These examples show that references, when taken in isolation, are not necessarily a sufficient indicator of the discussion being on-task. It is important to consider them in the context and in combination with other references. 
Next, the discussion will address what these findings mean in terms of communication design, conflict, and institutional talk.

\section{Discussion}

\subsection{Social epistemology and social relations in custody mediation}

54 The prior research focused on various aspects of references from the techniques and resources for formulating references to the role of references in accomplishing actions, but not on the use of references in shaping an activity. On the one hand, references can be signals of what activity interactants engage in. On the other hand, by calling different aspects of the world the interactants contribute to creating an activity. Regardless of how technical the word choice is, references to a certain object, a matter, and a person can serve as an indicator of an on-task mode of the interaction. For example, participants of mediation sessions may use a technical term (e.g., "visitation order") or more "lay" vocabulary (e.g., "plan") to refer to the interactional product. In both cases, they show their orientation toward the task at hand.

The use of references can be a sign of interactional asymmetry in institutional context. For example, the mediator makes references to interactional products, institutional professionals related to the process of dispute resolution (e.g., the judge, attorneys, mediators, court), clients, abstract people more often than other participants of the session, whereas the disputants make more references to people from their surrounding (e.g., their family members, acquaintances, babysitters, neighbors) and the police than the mediators. This can be attributed to different roles and knowledge interactants have, which is in agreement with other studies of institutional talk (see e.g., Drew \& Heritage, 1992). The mediator has more knowledge of institutional nature, that is, knowledge about the mediation system and alternative ways to resolve the dispute, and shares this information with the disputants. The disputants have knowledge of a more personal kind. They inform the mediator about their particular case. In terms of participation roles, the mediator has to ensure the development of the discussion in the institutionally preferred direction (i.e., to reach an institutional goal of custody mediation). Making certain types of references (e.g., interactional products) helps the mediator keep the disputants focused on the task and bring them back on track if they go off-task. It is a kind of signaling that frames interactivity. The disputants, in their turn, have their own interests in the outcome of the discussion. They refer to people, events, things that may help them appear in a more positive light while damaging the image of the opponent. Thus, references can be evidence of tension between different interactional goals. But, how are these basic features of organizing the interaction related to and consequential for constructing a particular type of interactivity and conflict management? The next section discusses the interplay between reference use, design, and conflict in institutional context. 


\subsection{Communication Design} 166). They design the trajectory of activity for disputants to take up, while being part of this activity. They work with the resources that are available in this interaction. Mediators can construct an institutionally preferred interactivity with help of on-task topics (Vasilyeva, 2012a) and dialogue activities (Vasilyeva, 2012b). At the same time, shaping an activity is accomplished at a micro level, for example, by employing different kinds of references. References are used to perform actions. With help of certain types of references the mediators set up a specific task for the disputants to accomplish, keep them focused on that task, and bring the interaction back on track when the disputants shift to an off-task mode. References are also indicators of what the interactants are doing at a given moment. References used by the mediators indicate their orientation toward the business at hand. At the same time, references the disputants make can be an indicator for the mediator if they are orienting toward the task, too. Thus, references serve as a means of coordinating an activity and indicative of the double design process. References are used to gear the interaction toward creating an interactional product. At the same time, to construct on-task/off-task modes, interactants have to signal what they are doing. References in this case are a metacommentary on what kind of interaction is unfolding.

58 The essence of communication design (Aakhus, 2007) is that it is an intentional act (although, certainly, designs can emerge through no overseeing actors). The designer develops a form of interactivity with an aim of shaping the content and outcome of the activity. However, an important and, at the same time, challenging aspect of being a designer in the situation is that the design situation is always evolving. The disputants bring their own interests into interaction; they can resist the mediators' actions or take an advantage of them. Thus, the mediator has to adapt to the situation as it unfolds. For example, in excerpt 3 discussed earlier, the mediator makes reference to money in the way that allows the ex-husband to continue bringing in the financial aspect into the discussion. The mediator adjusts to the situation and makes communicative moves to change the trajectory of the discussion by bringing in the interactional product as a focal point and financial issues as, although important, a peripheral matter at that moment. The mediator also employs references to the professionals such as the judge and attorneys, who can help the disputants with the financial aspect. In this way, the mediator's moves put constraints on the development of the discussion by connecting 
the desired product (i.e., a plan) with the designing system (i.e., a coalition of actors interactants) and the situation and by associating the undesired matter (i.e., the financial aspect) with actors outside of the situation (e.g., the judge and the attorneys).

The routine institutional practices mediators use for keeping the disputants on task constrain what is arguable and help them manage conflict. Making references to things, people, and matters that are connected with the process of dispute resolution helps keep the interaction within the limits of the institutionally defined task and contribute to shaping its quality. For example, the mediator's bringing in agents of an organization (e.g., excerpt 3) shuts down an opportunity for having an argument. Using different types of reference, the mediators shape disagreement space.

\section{Conclusion}

The prior research demonstrated that lexical dimension plays an important part in the organization of talk-in-interaction (e.g., Drew \& Heritage, 1992; Kitzinger \& Mandelbaum, 2013; Muraru, 2012; Oh, 2007). It indicated that vocabulary items can contribute to mitigating conflict situation (Muraru, 2012) or become the substance of a complaint (Kitzinger \& Mandelbaum, 2013) and be challenged by other interactants. In a similar vein, the article has examined different references to see how these terms are used to perform actions and to create on-task and off-task modes of interaction. How actions are approached in this article does not exclude other possible ways of treating actions (e.g., making references to criticize or to praise among others). This article, however, primarily has focused on how interactants use references to shape and signal an activity at a micro level. The article has demonstrated that the types of references employed to create an institutionally preferred form of interactivity are references to interactional products (e.g., a plan and an agreement), people outside of the immediate situation (references to children, agents of an organization such as judges, counselors, and lawyers, clients, and abstract people), and external matters related to the agenda of the meeting (e.g., references to custody and visitation matters and the process disputants have to go through to resolve their dispute). These references perform a number of functions such as setting a task before the disputants, keeping the discussion focused on task or showing that the conversation is off-task. Thus, by employing these types of references, mediators evoke the institutional context of talk and construct a format for disputants to deal with their conflict. In this way, the article contributes to further understanding of the role of interactional resources to shape a specific form of interactivity and to manage conflict.

\section{BIBLIOGRAPHY}

Aakhus, M. (2003) Neither Naïve nor Normative Reconstruction: Dispute Mediators, Impasse, and the Design of Argumentation, Argumentation: An International Journal on Reasoning, 17, p. 265-290. 
Aakhus, M. (2007) Communication as Design, Communication Monographs, 74, p. 112-117.

Bilmes, J. (2001) Tactics and Styles in the 1992 Vice Presidential Debate: Question Placement, Research on Language and Social Interaction, 34, p. 151-181.

Black, L. W. \& A. Wiederhold (2014) Discursive Strategies of Civil Disagreement in Public Dialogue Groups, Journal of Applied Communication Research, 42, p. 285-306.

Bonito, J. A. \& R. E. Sanders (2002) Speakers' Footing in a Collaborative Writing Task: A Resource for Addressing Disagreement While Avoiding Conflict, Research on Language and Social Interaction, 35, p. 481-514.

Bush, R. B. \& J. Folger (2005) The Promise of Mediation: Responding to Conflict through Empowerment and Recognition, San Francisco: Jossey-Bass Publishers, 287 p.

Coulter, J. (1990) Elementary Properties of Argument Sequences, in G. Psathas (ed.) Studies in Ethnomethodology and Conversation Analysis, Boston: University Press of America, p. 181-203.

Donohue, W. (1991) Communication, Marital Dispute, and Divorce Mediation, Hillsdale, New Jersey: Erlbaum, $256 \mathrm{p}$.

Drew, P. \& J. Heritage (1992) Analyzing Talk at Work: An Introduction, in Drew, P. \& J. Heritage (eds.) Talk at Work, Cambridge: Cambridge University Press, p. 3-65.

Garcia, A. C. (2000). Negotiating Negotiation: The Collaborative Production of Resolution in Small Claims Mediation Hearings, Discourse Studies, 11, p. 315-343.

Gillispie, J. \& J. H. Chrispeels (2008) Us and Them: Conflict, Collaboration, and the Discursive Negotiation of Multishareholder Roles in School District Reform, Small Group Research, 39, p. 397-437.

Goodwin, Ch. \& M. H. Goodwin (1990) Interstitial Argument, in A. D. Grimshaw (ed.) Conflict Talk: Sociolinguistic Investigations of Arguments in Conversations, Cambridge: Cambridge University Press, p. 85-117.

Greco Morasso, S. (2011) Argumentation in Dispute Mediation: A Reasonable Way to Handle Conflict, Amsterdam/Philadelphia: John Benjamins, 291 p.

Hoskins, M. L. \& J.-A. M. Stoltz (2003) Balancing on Words: Human Change Process in Mediation, Conflict Resolution Quarterly, 20, p. 331-349.

Houwen, F. van der (2009) Formulating Disputes, Journal of Pragmatics, 41, p. 2072-2085.

Hutchby, I. (1996) Confrontation Talk: Arguments, Asymmetries, and Power on Talk Radio, Mahwah, NJ: Lawrence Erlbaum Associates, $130 \mathrm{p}$.

Jackson, S. (1992) "Virtual Standpoints" and the Pragmatics of Conversational Argument, in Eemeren, F. H. van, Grootendorst, R., Blair, J. A. \& C. Willard (eds.) Argumentation Illuminated, Amsterdam: SicSat, p. 260-269.

Jackson, S. \& M. Aakhus (2014) Becoming more Reflective about the Role of Design in Communication, Journal of Applied Communication Research, 42, p. 125-134.

Jacobs, S. \& M. Aakhus (2002) What Mediators Do with Words: Implementing Three Models of Rational Discussion in Dispute Mediation, Conflict Resolution Quarterly, 20, p. 177-204.

Jefferson, G. (1996) On the Poetics of Ordinary Talk, Text and Performance Quarterly, 16, p. 11-61.

Kangasharju, H. (1996) Aligning as a Team in Multiparty Conversation, Journal of Pragmatics, 26, p. 291-319. 
Kangasharju, H. (2002) Alignment in Disagreement: Forming Oppositional Alliances in Committee Meetings, Journal of Pragmatics, 34, p. 1447-1471.

Kitzinger, C. \& J. Mandelbaum (2013) Word Selection and Social Identities in Talk-in-Interaction, Communication Monographs, 80, p. 176-198.

Kitzinger, C., Shaw, R. \& M. Toerien (2012) Referring to Persons without Using a Full-form Reference: Locally Initial Indexicals in Action, Research on Language and Social Interaction, 45, p. 116-136.

Kushida, S. (2015) Using Names for Referring without Claiming Shared Knowledge: Name-Quoting Descriptors in Japanese, Research on Language and Social Interaction, 48, p. 230-251.

Land, V. \& C. Kitzenger (2007) Some Uses of Third-Person Reference Forms in Speaker SelfReference, Discourse Studies, 9, p. 493-525.

Lerner, G. H. \& C. Kitzinger (2007) Extraction and Aggregation in the Repair of Individual and Collective Self-Reference, Discourse Studies, 9, p. 526-557.

Lerner, G. H., Bolden, G. B., Hepburn, A. \& J. Mandelbaum (2012) Reference Recalibration Repairs: Adjusting the Precision of Formulation for the Task at Hand, Research on Language and Social Interaction, 45, p. 191-212.

Maoz, I. \& D. G. Ellis (2001) Going to Ground: Argument in Israeli-Jewish and Palestinian Encounter Groups, Research on Language and Social Interaction, 34, p. 399-419.

McVittie, Ch., Sambaraju, R. \& A. McKinlay (2011) “There will Only be Lots of Chit-Chat”: How Hamas Leaders and Media Interviewers Handle Controversial Topics, Research on Language and Social Interaction, 44, p. $92-105$.

Muraru, D. (2012). Strategic Maneuvering in Diplomatic Mediation. Journal of Argumentation in Context, 1, p. 331-337.

O'Donnell, K. (1990) Differences and Dominance: How Labor and Management Talk Conflict, in A. D. Grimshaw (ed.) Conflict Talk: Sociolinguistic Investigations of Arguments in Conversations, Cambridge: Cambridge University Press, p. 210 - 240.

Oh, S.-Y. (2007) Overt Reference to Speaker and Recipient in Korean, Discourse Studies, 9, p. 462-492.

Olekalns, M., Brett, J. \& W. Donohue (2010) Words are All I Have: Linguistic Cues as Predicators of Settlement in Divorce Mediation, Negotiation and Conflict Management Research, 3, p. 145-168.

Pinto, J. (2000) Peacemaking as Ceremony: The Mediation Model of the Navajo Nation, International Journal of Conflict Management, 11, p. 267-286.

Putnam, L. L. (2009) Exploring the Role of Communication in Transforming Conflict Situations: A Social Construction Approach, in Galanes, G. J. \& W. Leeds-Hurwitz (eds.) Socially Constructing Communication, Cresskill, NJ: Hampton Press, p. 189 - 209.

Sacks, H. \& E. A. Schegloff (1979) Two Preferences in the Organization of Reference to Persons in Conversation and Their Interaction, in G. Psathas (ed.) Everyday Language: Studies in Ethnomethodology, New York, NY: Irvington Press, p. 15-21.

Schegloff, E. A. (1972) Notes on a Conversational Practice: Formulating Place, in D. N. Sudnow (ed.) Studies in Social Interaction, New York: Free Press, p. 75-119. 
Schegloff, E. A. (1996) Some Practices for Referring to Persons in Talk-in-Interaction: A Partial Sketch of a Systematics, in B. A. Fox (ed.) Studies in Anaphora, Philadelphia: John Benjamins Publishing, p. 437-485.

Schegloff, E. A. (2007) Categories in Action: Person-Reference and Membership Categorization, Discourse Studies, 9, p. 433-461.

Schenkein, J. (1978) Studies in the Organization of Conversational Interaction, New York: Academic Press, $275 \mathrm{p}$.

Schiffrin, D. (1990) The Management of a Co-operative Self during Argument: The role of Opinions and Stories, in Grimshaw, A. D. (ed.) Conflict Talk: Sociolinguistic Investigations of Arguments in Conversations, Cambridge, UK: Cambridge University Press, p. 241-259.

Schön, D. \& M. Rein (1994) Frame Reflection: Towards the Resolution of Intractable Policy Controversion, New York: Basic Books, 247 p.

Sprain, L., Carcasson, M. \& A. J. Merolla (2014) Utilizing “on Top” Experts in Deliberative Forums: Implications for Design, Journal of Applied Communication Research, 42, p. 150-167.

Stokoe, E. \& R. Sikveland (2016) Formulating Solutions in Mediation, Journal of Pragmatics, 105, p. 101-113.

Tabucanon, G. M. P., Wall, Jr., J. A. \& W. Yan (2008) Philippine Community Mediation, Katarungang Pambarangay, Journal of Dispute Resolution, 2, p. 501-513.

Tracy, K. (2010) Challenges of Ordinary Democracy: A Case Study in Deliberation and Dissent, University Park, PA: The Pennsylvania State University, 251 p.

Tracy, K. (2011) What's in a Name? Stance Markers in Oral Argument about Marriage Laws, Discourse and Communication, 5, p. 1-23.

Vasilyeva, A. L. (2012a) Topics as Indication of Being On-task/Off-task, Empedocles: European Journal for the Philosophy of Communication, 3, p. 61-82.

Vasilyeva, A. L. (2012b) Argumentation in the Context of Mediation Activity, Journal of Argumentation in Context, 1, p. 209-233.

Vasilyeva, A. L. (2015a) Mediation Discourse, in Tracy, K., Ilie, C. \& T. Sandel (eds.) The International Encyclopedia of Language and Social Interaction, Boston, MA: John Wiley \& Sons, p. 973-977.

Vasilyeva, A. L. (2015b) Identity as a Resource to Shape Mediation in Dialogic Interaction, Language and Dialogue, 5, p. 355-380.

Vasilyeva, A. L. (2016a) Mediation Discourse in the United States and Belarus: Culturally Shaped Interactions, in D. Carbaugh (ed.) The Handbook of Communication in Cross-cultural Perspective, New York and London: Routledge, p. 273-284.

Vasilyeva, A. L. (2016b) Confrontation and Collaboration in the Course of the Election Debate, Language and Dialogue, 6, p. 379-394.

Vasilyeva, A. L. (2017) Practices of Topic and Dialogue Activity Management in Dispute Mediation, Discourse Studies, 19, p. 341-358.

Wall, J. A., Beriker, N. \& S. Wu (2010) Turkish Community Mediation, Journal of Applied Social Psychology, 40, p. 2019-2042.

Wall, J. A. \& S. Chan-Serafin (2014) Friendly Persuasion in Civil Case Mediations, Conflict Resolution Quarterly, 31, p. 285-303. 
Whitehead, K. \& G. H. Lerner (2009) When are Persons "White"? On Some Practical Asymmetries of Racist Reference in Talk-in-Interaction, Discourse and Society, 20, p. 613-641.

Winslade, J. \& G. Monk (2008) Practicing Narrative Mediation: Loosening the Grip of Conflict, San

Francisco: Jossey-Bass Publishers, 315 p.

\section{APPENDIXES}

\section{Appendix: Transcription Conventions}

\begin{tabular}{|l|l|}
\hline$[$ ] & overlapping talk \\
\hline (word) & talk that the transcriber is not sure about \\
\hline ( ) & indecipherable talk \\
\hline word- & a word was cut off abruptly \\
\hline$(($ PAUSE) $)$ & pause \\
\hline$(($ smile)) & nonverbal action \\
\hline. & falling intonation \\
\hline, & rising intonation \\
\hline$\ldots$ & omitted part \\
\hline = & latching \\
\hline M & mediator \\
\hline W & (ex)-husband \\
\hline
\end{tabular}

\section{NOTES}

1. Mediators' practices may vary depending on the type and model of mediation (see, e.g., Jacobs and Aakhus (2002) on three models of dispute mediation) and/ or culture (e.g., Pinto (2000), Tabucanon et al. (2008), Vasilyeva (2016a), Wall et al. (2010)).

2. The transcripts used in the present study were made by Deborah Weider-Hatfield for Dr. William Donohue's project on communication practices in divorce mediation (Donohue, 1991). These transcripts were made available to me by Dr. Scott Jacobs. The transcription of the audiotapes followed the scheme developed for conversation analysis and outlined in Schenkein (1978).

3. See Appendix for the transcription conventions.

4. A longer version of this episode appears in Vasilyeva (2016a) with focus on a cultural aspect of mediation talk. 
5. A longer version of this episode and its detailed analysis appear in Vasilyeva (2017) to illustrate a session-centered type of interventions mediators perform to terminate an inappropriate topic.

\section{ABSTRACTS}

This article examines references interactants make in the course of mediation sessions with the purpose of understanding how these references serve as indicators of the mediation session being on-task or off-task and a type of interactional resources mediators use to manage conflict. An existing collection of transcripts from audio recordings of mediation sessions at a mediation center in the western United States serves as a source of interactional data. The study identified references that are employed to create an institutionally preferred form of the interactivity, namely, references to interactional products (e.g., a plan and an agreement), people outside of the immediate situation (references to children, agents of an organization such as judges, counselors, and lawyers, clients, and abstract people), and external matters related to the agenda of the meeting (e.g., references to custody and visitation matters and the process disputants have to go through to resolve their dispute). The analysis shows that these references perform a number of functions such as setting a task before the disputants, keeping the discussion focused on task or showing that the conversation is off-track. It indicates that there are differences in mediators' and disputants' usage of references, for example, in terms of the use of linguistic tokens, frequency, and what they refer to. The article also demonstrates that it is important to consider references in the context and in combination with other references, as, when taken in isolation, they are not necessarily a sufficient indicator of the discussion being on-task. Finally, the article discusses what the findings mean in terms of conflict, communication design, and institutional talk.

L'objectif du présent article est d'examiner la médiation des disputes pendant laquelle les médiateurs aident les couples divorcés ou ceux qui sont en train de divorcer à développer des arrangements pour la garde d'enfants et les règles de visite. Les transcriptions faites à partir des enregistrements audio de séances de médiation recueillis dans un centre de médiation à l'ouest des États-Unis servent de données pour l'analyse. Les 18 transcriptions utilisées dans la présente étude proviennent des séances tenues pour un programme public de médiation de divorce liée à un tribunal où le juge approuve la décision. Plus précisément, cette étude examine les références (c'est-à-dire., les éléments que les interactants mentionnent dans la conversation) auxquelles les participants ont eu recours lors des séances de médiation dans le but de comprendre comment ces références servent d'indicateurs pour savoir si la séance de médiation est en tâche ou horstâche et de connaître le type de ressources interactionnelles que les médiateurs utilisent pour gérer les conflits. La recherche utilise la méthode d'analyse du discours et se sert de l'approche du design de la communication. Cette approche considère la communication comme un objet de design et un processus de design (Aakhus, 2007). Le design de la communication a lieu lorsque les interactants interviennent dans une activité communicative avec l'aide des techniques et des procédures pour modifier cette activité dans le but d'atteindre certaines fins.

L'étude a identifié les références qui sont utilisées pour créer une forme institutionnelle préférée de l'interactivité, à savoir les références aux produits interactionnels (par exemple, un plan et un contrat), les personnes en dehors de la situation immédiate (références aux enfants, agents d'une 
organisation tels que les juges, les conseillers, les avocats, ou encore les clients et des personnes abstraites), et les questions externes liées à l'ordre du jour de la réunion (par exemple, les références aux questions de garde et de visite et au processus par lequel les deux parties doivent passer pour régler leur différend). Cela montre que ces références remplissent un certain nombre de fonctions. Elles sont utilisées pour poser une tâche devant les parties en litige, pour tenir la discussion centrée sur la tâche ou pour signaler que la conversation est hors-tâche. L'étude indique également qu'il existe des différences dans l'utilisation des références par les médiateurs et les parties adverses, par exemple, en termes d'utilisation de la terminologie, la fréquence, ainsi que de ce à quoi ils se réfèrent. L'utilisation de références peut alors être un signe d'asymétrie d'interaction dans le contexte institutionnel. L'étude signale, enfin, qu'il est important de tenir compte des références dans le contexte et en combinaison avec d'autres références. Si chaque référence est prise isolément, une référence n'est pas nécessairement un indicateur suffisant que la discussion est sur la tâche. En employant des références, les médiateurs évoquent le contexte institutionnel de la conversation et construisent un format pour les parties adverses pour gérer leur conflit. L'article discute également de la signification de ces résultats en termes de conflit, de design de la communication et de discours institutionnel.

\section{INDEX}

Mots-clés: Mots-clés: conflit, design de la communication, discours institutionnel, médiation des différends, références

Keywords: Keywords: communication design, conflict, dispute mediation, institutional talk, references

\section{AUTHOR}

\section{ALENA L. VASILYEVA}

Department of Communication, University of Massachusetts Amherst, Amherst MA, USA

vasilyeva@umass.edu 